\title{
ANALISIS GENETIK AYAM TOLAKI PADA MASA PERTUMBUHAN
}

\author{
Rusli Badaruddin ${ }^{1}$, La Ode Nafiu ${ }^{1}$, Muh.Amrullah Pagala ${ }^{1}$ \\ ${ }^{1}$ Fakultas Peternakan, Universitas Halu Oleo Kendari \\ * e-mail: rbadaruddin79@yahoo.com
}

\begin{abstract}
ABSTRAK
Ayam Tolaki merupakan ayam lokal Konawe, Konawe Selatan, Sulawesi Tenggara. Penelitian ini bertujuan untuk mengetahui dan mempelajari Sifat fenotip dan genetik pada pertumbuhan ayam Tolaki. Dari 5 kelompok perkawinan 5 ekor pejantan dan 15 ekor induk masing-masing kelompok 1 ekor pejantan dengan 3 ekor induk dihasilkan 144 ekor anak ayam Tolaki yang terdiri dari (78 ekor jantan dan 66 ekor betina), yang diberi pakan secara adlibitum. Pengamatan meliputi :, Komponen variansi digunakan untuk mengistimasi nilai-nilai genetik (heritabilitas) sifat pertumbuhan ayam Tolaki. Hasil penelitian menunjukan pertumbuhan ayam jantan lebih cepat dibandingkan ayam betina . kemampuan sifat pertumbuhan ayam Tolaki berdasarkan komponen variansi jantan, betina dan variansi induk cukup berfluktuasi. Pewarisan sifat pertumbuhan berdasarkan komponen variansi jantan $\left(\hat{\mathrm{h}}^{2}{ }_{\mathrm{s}}\right)$ tinggi pada umur 0 sampai 12 minggu dan bernilai positif
\end{abstract}

Kata kunci : Genetik, Heritabilitas, Ayam Tolaki dan Pertumbuhan

\begin{abstract}
Chicken Tolaki a local chicken Konawe, Konawe South, South-East of Sulawesi. This study aims to identify and study the nature of the phenotypes and genetic Tolaki in the growth of chicken. Of the 5 groups of birds mating 5 men and 15 farms each group 1 with 3 tail tail male parent produced 144 chicks Tolaki consists of (78 males and 66 females) that was given feed by adlibitum. Observations included: Components of variance was used to estimate the values of Genetics (heredity) growth of chicken Tolaki properties. The results showed The growth of male chicken is faster than a rooster chicken one. The inheritance of growth based on the nature of the components of male variance is high at the $\left(\hat{\mathrm{h}}_{\mathrm{s}}^{2}\right)$ age of 1-5 weeks that is about $0.3-0.54$.
\end{abstract}

Key words : Genetic, Heritability, Chicken Tolaki and Growth

*) Corresponding author 


\section{PENDAHULUAN}

Ayam lokal di Indonesia adalah kekayaan alam yang merupakan aset nasional yang tidak ternilai harganya. Beberapa diantaranya merupakan cikal bakal bagi ayam ras yang dikembangkan diluar negeri. Indonesia dikenal sebagai negara yang memiliki keanekaragaman hayati (Biodiversity) yang tinggi termasuk ayam piaraan. Ayam piaraan yang ada sekarang ini diperkirakan berasal dari keturunan ayam hutan merah (Gallus gallus) dan ayam hutan hijau (Gallus varius) (Iswanto, 2005).

Hasil identifikasi perkembangbiakan ayam piaraan atau ayam lokal Indonesia, diketahui telah terdapat 27 jenis ayam lokal yang memiliki karakteristik penampilan yang khas (Natamidjaja dan Dwiyanto, 1994) dan Anonimous (2008) melaporkan terdapat lebih kurang 31 galur ayam asli Indonesia.

Ayam Tolaki adalah ayam asli Sulawesi Tenggara yang tersebar di beberapa daerah seperti Kabupaten Konawe dan Konawe Selatan. Namun demikian informasi karakteristik ayam Tolaki sebagai ayam khas Sulawesi Tenggara belum banyak dilaporkan, baik karakter fenotip maupun genotipnya, termasuk potensi produktivitas dan reproduktivitasnya. Hasil penelitian awal diketahui bahwa ayam Tolaki banyak digunakan sebagai ayam sabungan (Nafiu dan Rusdin, 2007). Sementara Sarwono (2007) menyatakan ayam Tolaki cocok dikembangkan sebagai ayam petelur. Hasil penelitian awal diketahui bahwa ayam

Tabel 1. Susunan dan Kandungan Nutrien Pakan Pejantan dan Induk

\begin{tabular}{cccccccc}
\cline { 3 - 8 } Bahan pakan & Jumlah & \multicolumn{7}{c}{ Kandungan nutrien } \\
\cline { 3 - 8 } & $(\%)$ & ME & CP & LK & SK & Ca & P \\
\hline Jagung & 60,0 & 2060,0 & 5,4 & 2,28 & 1,50 & 0,012 & 0,132 \\
Bekatul & 9,0 & 146,7 & 0,75 & 0,71 & 0,74 & 0,009 & 0,117 \\
Konsentrat & 30,0 & 570,0 & 9,90 & 1,50 & 2,40 & 3,600 & 0,450 \\
Mineral & 1,0 & - & - & - & - & 0,325 & 0,100 \\
Top Mix & 0,7 & - & - & - & - & - & - \\
\hline Jumlah & 100,7 & 2776,7 & 16,05 & 4,49 & 4,64 & 3,946 & 0,799 \\
\hline
\end{tabular}

Tolaki banyak digunakan sebagai ayam sabungan. Sabung ayam Tolaki biasanya diperagakan sebagai bagian dari pertunjukan seni budaya lokal di Sulawesi Tenggara.

Penelitian yang mempelajari aspek biologis dan genetik pada ayam Tolaki belum dilaksanakan, sehingga data potensi produksi, efisiensi pemeliharaan belum banyak diketahui. Sebagai langkah awal penelitian ini dilakukan untuk mengetahui potensi yang dimiliki tentang sifat genetik ayam Tolaki pada masa pertumbuhan.

Penelitian ini dilaksanakan selama lima bulan yang bertempat di kandang unggas jurusan Peternakan Fakultas Pertanian Universitas Haluoleo Kendari. Materi penelitian ayam Tolaki jantan dan induk yang terpilih secara acak dengan umur dan berat yang relatif sama sebanyak 5 ekor pejantan dan 15 ekor induk, keturunan dari hasil perkawinan berupa DOC unsexed sebanyak 144 ekor diteliti dan diamati pertumbuhannya mulai umur 0 sampai umur 12 minggu. Pakan yang digunakan untuk pejantan dan induk adalah pakan yang biasa digunakan di Universitas Haluoleo Kendari dengan komposisi dan kandungan nutrien (Tabel 1).

Pakan yang digunakan untuk keturunan ayam Tolaki mulai umur 0 sampai umur 12 minggu disusun sendiri dengan susunan bahan pakan dan kandungan nutrien disajikan pada Tabel 2.

\section{MATERI DAN METODE}


Tabel 2. Susunan dan Kandungan Nutrien Pakan Keturunan Ayam Tolaki

\begin{tabular}{cccccc}
\hline \multirow{2}{*}{ Bahan Pakan } & Proporsi & \multicolumn{4}{c}{ Kandungan Nutrien } \\
\cline { 2 - 6 } & $(\%)$ & $\mathrm{CP}(\%)$ & $\begin{array}{c}\text { ME } \\
(\mathrm{kcal})\end{array}$ & $\mathrm{Ca}$ & $\mathrm{P}$ \\
\hline Jagung & 33 & 28,050 & 1112,2 & 0,017 & 0,488 \\
Tepung Ikan & 25 & 72,520 & 1100,5 & 1,150 & 0,192 \\
Dedak Padi & 17,5 & 22,925 & 437,5 & 0,011 & 0,128 \\
Konsentrat Layer & 24,5 & 81,200 & 558,5 & 2,440 & 0,368 \\
\hline Jumlah & 100,00 & 20,95 & 3208,7 & 3,618 & 1,176 \\
\hline
\end{tabular}

Alat yang digunakan dalam penelitian ini adalah kandang individu sistim baterei sebanyak 50 buah. Kandang untuk anak ayam atau keturunan digunakan kandang breeding sistim litter. Alat lain adalah timbangan digital kapasitas $2 \mathrm{~kg}$ dengan kepekaan 0,1 gram, timbangan untuk pakan berkapasitas $5 \mathrm{~kg}$ dan $10 \mathrm{~kg}$, mesin tetas listrik berkapasitas 250 butir jangka sorong digital, pita ukur dan alat tulis menulis. Jalannya penelitian diawali dengan pengaturan perkawinan dari 5 ekor pejantan dengan 15 ekor betina.Masing-masing pejantan kawin dengan 3 ekor induk. Telur yang dihasilkan diidentifikasi dan diberi kode sesuai tetua (jantan dan induk), dikumpulkan kemudian ditetaskan.

Pengumpulan telur tetas dilakukan setiap hari dan penetasan dilakukan 2 minggu sekali sampai jumlah DOC yang diharapkan dapat terpenuhi yaitu minimal 10 butir perinduk. DOC yang sudah diidentifikasi dengan jelas berdasarkan tetua pejantan dan induk diberi kode, kemudian ditimbang untuk mengetahui berat awal.

Tabel 3. Jumlah Anak Ayam Tolaki Hasil Lima Kelompok Perkawinan Berdasarkan Jenis Kelamin Yang Digunakan Dalam Penelitian

\begin{tabular}{lll}
\hline Komponen & Kelompok perkawinan & Total
\end{tabular}

\begin{tabular}{lccccccccccccccccc}
\hline Pejantan & & 1 & & & 2 & & & 3 & & & 4 & & & 5 & \\
Induk & 1 & 2 & 3 & 1 & 2 & 3 & 1 & 2 & 3 & 1 & 2 & 3 & 1 & 2 & 3 & 15 \\
\hline Keturunan: & & & & & & & & & & & & & & & & & \\
Jantan & 6 & 7 & 7 & & 5 & 4 & 4 & 4 & 5 & 4 & 5 & 5 & 7 & 6 & 5 & 78 \\
Betina & 2 & 3 & 2 & 6 & 6 & 6 & 5 & 5 & 5 & 5 & 4 & 6 & 3 & 4 & 4 & 66 \\
Jumlah & 8 & 10 & 9 & 10 & 11 & 10 & 9 & 9 & 10 & 9 & 9 & 11 & 10 & 10 & 9 & 144 \\
\hline
\end{tabular}

Struktur data ini disusun berdasarkan struktur data hierarkis (Nested design). 
Parameter yang diamati

Data diperoleh berdasarkan penimbangan dan pengamatan setiap minggu pada masing-masing individu. Data yang dikumpulkan yaitu berat badan, dan pertambahan berat badan

\section{Analisis Data}

Data penelitian di analisis dengan menggunakan analisis variansi CRD pola nested design (struktur hierarkis) untuk mendapatkan komponen varian dari jantan dan betina

Model matematiknya adalah sebagai berikut :

$$
Y_{i j k}=\mu+J_{i}+\beta_{i j}+\varepsilon_{i j k}
$$

Keterangan :

$\mathrm{Y}_{\mathrm{ijk}}=$ Nilai pengamatan dari keturunan, $\mathrm{I}=$ pakan, $\mathrm{k}=$ betina, $\mathrm{j}=$ jantan, $\mu=$ Rata-rata umum dari pengamatan

$$
\begin{aligned}
& \mathrm{J}_{\mathrm{i}} \quad=\text { Pengaruh jantan (i } \\
& =1,2, \ldots .5) \\
& \mathrm{j}=1,2, \ldots 10) \text { dalam jantan }(\mathrm{i}=1,2, \ldots 5) \\
& \varepsilon_{\mathrm{ijk}} \quad=\text { Pengaruh } \\
& \text { keturunan ke-I untuk } \\
& \text { masing-masing jantan ke-I } \\
& \text { dan betina ke-j }
\end{aligned}
$$

\section{Komponen variansi}

Melalui analisis statistik berdasarkan struktur hierarkis (nested

\begin{tabular}{|c|c|c|c|c|}
\hline Sumber Variansi & $\begin{array}{l}\text { Derajat } \\
\text { bebas }\end{array}$ & Jumlah kuadrat & Rata-rata kuadrat & $\begin{array}{l}\text { Rata-rata kuadrat } \\
\text { kelompok }\end{array}$ \\
\hline Diantara pejantan & $\mathrm{v}-1$ & $\sum \mathrm{X}^{2} \mathrm{i} . .-\mathrm{C}$ & $\mathrm{SSjtn} /(\mathrm{v}-1)$ & $\sigma^{2} €+\mathrm{k} 1 \sigma^{2} q+$ \\
\hline Diantara Betina & $\mathrm{v}(\mathrm{m}-1)$ & $\Sigma \mathrm{X}^{2 \mathrm{ij} .}-\Sigma \mathrm{X}^{2} \mathrm{i} .$. & $\operatorname{SSbtn} / \mathrm{v}(\mathrm{m}-1)$ & $\mathrm{k} 2 \sigma^{2} \sigma^{x}$ \\
\hline Diantara & $\operatorname{vm}(n-1)$ & $\bar{\Sigma} X^{2} i j k-\bar{\Sigma} X^{2 i j}$ & SSket/vm $(n-1)$ & $\sigma^{2} \epsilon+\mathrm{k} 3 \sigma^{2}+$ \\
\hline Keturunan & & & & $\sigma^{2} \epsilon$ \\
\hline TOTAL & Vmn-1 & & - & $\begin{array}{l}\sigma^{2} T=\sigma^{2} \epsilon+\sigma^{2} q+ \\
\sigma^{2} \sigma^{2}\end{array}$ \\
\hline
\end{tabular}
design) dihitung komponen variansi diantara jantan, diantara betina dalam jantan dan diantara keturunan dalam betina dan jantan. Perkiraan estimasi genetik berdasarkan komponen variansinya tertera pada Tabel 4.

Tabel 4 . Struktur analisis variansi nested design (struktur hirarkis)

$\sigma s^{2}$ : komponen variansi jantan $\sigma^{2} €$ : komponen variansi keturunan/individual error $\sigma \mathrm{d}^{2}$ : komponen variansi betina

\section{Estimasi Heritabilitas $\left(\hat{\mathrm{h}}^{2}\right)$}

Estimasi nilai heritabilitas dihitung berdasarkan komponen variansi jantan $\left(\hat{\mathrm{h}}^{2}{ }_{\mathrm{s}}\right)$, komponen variansi betina $\left(\hat{\mathrm{h}}_{\mathrm{d}}^{2}\right)$ dan gabungan komponen variansi jantan dan betina $\left(\hat{\mathrm{h}}^{2}{ }_{\mathrm{s}+\mathrm{d}}\right)$ (Becker,1992), dapat dirumuskan sebagai berikut :

1. Berdasarkan komponen jantan $\left(\hat{\mathrm{h}}^{2}{ }_{\mathrm{s}}\right)$ :

$$
\hat{\mathrm{h}}_{\mathrm{s}}^{2}=\frac{4 \sigma s^{\mathrm{s}}}{\sigma s^{2}+\sigma \mathrm{d}^{\mathrm{s}}+\sigma^{2} \mathrm{~s}}
$$

2. Berdasarkan komponen betina $\left(\hat{\mathrm{h}}_{\mathrm{d}}^{2}\right)$ :

$$
\hat{\mathrm{h}}_{\mathrm{d}}^{2}=\frac{4 \sigma \mathrm{d}^{2}}{\sigma \mathrm{s}^{2}+\sigma \mathrm{d}^{2}+\sigma^{2} \mathrm{~g}}
$$

3. Berdasarkan komponen jantan dan betina $\left(\hat{\mathrm{h}}_{\mathrm{s}+\mathrm{d}}^{2}\right)$ :

$$
\hat{h}_{s+d}^{2}=\frac{2 \sigma(s+d)^{c}}{\sigma s^{2}+\sigma d^{4}+\sigma^{2} s}
$$

Keterangan :

$\hat{\mathrm{h}}_{\mathrm{s}}^{2}=$ Estimasi heritabilitas berdasarkan komponen jantan

$\hat{\mathrm{h}}_{\mathrm{d}}^{2} \quad=$ Estimasi heribalitas

berdasarkan komponen betina

$$
\hat{\mathrm{h}} 2\left(_{\mathrm{s}+\mathrm{d}}\right)=\text { Estimasi heritabilitas }
$$

berdasarkan komponen jantan dan betina 


\section{HASIL DAN PEMBAHASAN}

\section{Analisis Fenotip Ayam Tolaki}

\section{Berat Badan Keturunan Ayam Tolaki}

Rataan bobot badan keturunan Ayam Tolaki berdasarkan umur dan jenis kelamin dapat dilihat pada Tabel 4 .

Tabel 4. Rata-rata berat badan (g/ekor) keturunan ayam Tolaki berdasarkan umur dan jenis kelamin

\begin{tabular}{|c|c|c|c|c|c|c|c|c|c|}
\hline \multirow[b]{2}{*}{$0^{*}$} & \multirow[b]{2}{*}{ 우 } & \multirow[b]{2}{*}{$\mathbf{N}$} & \multirow{2}{*}{$\begin{array}{l}01 \\
0 \\
\end{array}$} & \multicolumn{3}{|c|}{ umur ( minggu ) } & \multirow[b]{2}{*}{ VIII } & \multirow[b]{2}{*}{$\bar{X}$} & \multirow[b]{2}{*}{ XII } \\
\hline & & & & II & IV & VI & & & \\
\hline \multirow[t]{8}{*}{1} & 1 & 8 & $0 / 6$ & $\begin{array}{c}83,35 \pm 1 \\
8,3 \\
75,75 \pm 1\end{array}$ & $\begin{array}{c}146,00 \pm 34 \\
, 5 \\
142,4 \pm 21\end{array}$ & $\begin{array}{c}215,97 \pm 70 \\
, 30 \\
190,05 \pm 10\end{array}$ & $\begin{array}{c}276,15 \pm 66 \\
13\end{array}$ & $325,71 \pm 80,23$ & $\begin{array}{c}433,53 \pm 87 \\
86\end{array}$ \\
\hline & & & 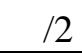 & 1,2 & 64 & ,96 & $231,7 \pm 5,23$ & $351,90 \pm 6,34$ & $, 65 \pm 8,41$ \\
\hline & 2 & 10 & $0 / 7$ & $\begin{array}{c}74,7 \pm 16 \\
52\end{array}$ & $\begin{array}{c}127,83 \pm 14 \\
, 0\end{array}$ & $\begin{array}{c}194,19 \pm 32 \\
, 17\end{array}$ & $\begin{array}{c}266,07 \pm 57 \\
73\end{array}$ & $320,14 \pm 78,79$ & $\begin{array}{c}397,66 \pm 83 \\
30\end{array}$ \\
\hline & & & & $25,27 \pm 2$ & $106,87 \pm 12$ & $139,47 \pm 3$ & $201,6 \pm 56,7$ & & $297,5 \pm 73,1$ \\
\hline & & & $9 / 3$ & 67 &, 17 & 62 & 3 & $251,97 \pm 68,55$ & 8 \\
\hline & 3 & 9 & $0^{\pi} / 7$ & $\begin{array}{c}71,23 \pm 8 \\
13\end{array}$ & $\begin{array}{c}128,37 \pm 9 \\
29\end{array}$ & $\begin{array}{c}160,01 \pm 33 \\
47\end{array}$ & $\begin{array}{c}236,03 \pm 40 \\
97\end{array}$ & $287,86 \pm 44,91$ & $\begin{array}{c}353,99 \pm 53 \\
83\end{array}$ \\
\hline & & & & $54,55 \pm 1$ & $82,75 \pm 23$ & $197,77 \pm 19$ & $188,55 \pm 25$ & & $306,05 \pm 21$ \\
\hline & & & 일 & 9,7 & 97 &, 61 & 67 & $250,10 \pm 4,67$ & 71 \\
\hline \multirow{11}{*}{2} & 1 & 10 & $0 / 4$ & $\begin{array}{c}69,58 \pm 1 \\
9,6\end{array}$ & $\begin{array}{c}126,55 \pm 30 \\
8\end{array}$ & $\begin{array}{c}178,03 \pm 51 \\
10\end{array}$ & $\begin{array}{c}219,48 \pm 53 \\
41\end{array}$ & $272.38+53.18$ & $\begin{array}{c}335,38 \pm 72 \\
63\end{array}$ \\
\hline & & & & $63,58 \pm 1$ & $109,18 \pm 18$ & $158,68 \pm 23$ & $226,22 \pm 52$ & & $328,13 \pm 71$ \\
\hline & & & 우 6 & 3,8 &, 3 &, 03 & 00 & $271,20 \pm 67,63$ & 70 \\
\hline & & & & $70,12 \pm 1$ & $107,58 \pm 13$ & $159,72 \pm 39$ & $227,36 \pm 53$ & & $327,96 \pm 60$ \\
\hline & 2 & 11 & $0^{*} / 5$ & 3,0 &, 4 &, 58 & 35 & $282,18 \pm 64,91$ & 24 \\
\hline & & & & $61,78 \pm 2$ & $102,58 \pm 30$ & $69,531 \pm 67$ & $221,37 \pm 74$ & & $335,52 \pm 99$ \\
\hline & & & 이 & 1,9 & ,2 &, 44 & 27 & $283,38 \pm 86,06$ & 06 \\
\hline & & & & $69,53 \pm 1$ & $114,40 \pm 13$ & $161,08 \pm 34$ & $232,60 \pm 57$ & & $354,85 \pm 13$ \\
\hline & 3 & 10 & $0 / 4$ & 5,8 &, 1 &, 56 & 75 & $296,40 \pm 98,81$ & 9,29 \\
\hline & & & & $77,34 \pm 1$ & $124,72 \pm 18$ & $190,80 \pm 42$ & $276,70 \pm 60$ & & $445,32 \pm 79$ \\
\hline & & & \%/6 & 5,6 &, 5 & ,28 & 60 & $376,96 \pm 69,11$ & 02 \\
\hline \multirow{12}{*}{3} & & & & $80,13 \pm 1$ & $121,20 \pm 8$ & $166,80 \pm 11$ & $215,85 \pm 7,7$ & & $292,65 \pm 22$, \\
\hline & 1 & 9 & $0^{\pi} / 4$ & 4,9 & 63 & ,29 & 8 & $253,20 \pm 9,92$ & 06 \\
\hline & & & & $60,58 \pm 2$ & $98,74 \pm 37$ & $147,60 \pm 45$ & $208,96 \pm 63$ & & $359,90 \pm 95$, \\
\hline & & & 아 /5 & 2,7 & 78 &, 73 & 02 & $274,44 \pm 75,85$ & 17 \\
\hline & & & & $77,58 \pm 1$ & $121,73 \pm 15$ & $172,10 \pm 16$ & $239,48 \pm 11$ & & $384,53 \pm 75$ \\
\hline & 2 & 9 & $0^{7} / 5$ & 5,8 & ,6 & ,15 & 94 & $302,30 \pm 34,29$ & 74 \\
\hline & & & & $42,78 \pm 9$ & $72,84 \pm 19$ & $102,14 \pm 14$ & $161,66 \pm 40$ & & $262,44 \pm 13$ \\
\hline & & 9 & + /4 & 06 & 91 &, 39 & 17 & $208,82 \pm 81,20$ & 4,18 \\
\hline & & & & $55,70 \pm 7$ & $99,86 \pm 16$ & $156,78 \pm 18$ & $220,48 \pm 17$ & & $361,34 \pm 79$ \\
\hline & 3 & 10 & $0^{2} / 5$ & 02 & 42 &, 72 & 91 & $294,20 \pm 43,44$ & 33 \\
\hline & & & & $59,16 \pm 7$ & $107,68 \pm 20$ & $146,40 \pm 29$ & $193,10 \pm 37$ & & $304,28 \pm 87$ \\
\hline & & & 우/5 & 21 &, 8 &, 04 & 71 & $249,02 \pm 68,40$ & 27 \\
\hline \multirow{7}{*}{4} & & & & $58,88 \pm 1$ & $111,18 \pm 11$ & $158,30 \pm 25$ & $235,75 \pm 28$ & & $370,68 \pm 71$ \\
\hline & 1 & 9 & $0 / 4$ & 8,9 & 6 &, 42 & 83 & $303,48 \pm 50,88$ & 26 \\
\hline & & & & $55,82 \pm 1$ & $95,66 \pm 12$ & $144,18 \pm 17$ & $189,46 \pm 17$ & & $307,12 \pm 67$ \\
\hline & & & ‡/5 & 3,0 & 10 &, 80 & 36 & $254,46 \pm 45,28$ & 45 \\
\hline & 2 & 9 & $0^{\top} / 5$ & $\begin{array}{c}60,22 \pm 7 \\
42\end{array}$ & $\begin{array}{c}107,08 \pm 11 \\
, 2\end{array}$ & $\begin{array}{c}156,80 \pm 27 \\
, 53\end{array}$ & $\begin{array}{c}209,46 \pm 27 \\
11\end{array}$ & $255,42 \pm 46,52$ & $\begin{array}{c}303,82 \pm 58 \\
07\end{array}$ \\
\hline & & & & $58,68 \pm 2$ & $92,50 \pm 35$ & $161,38 \pm 60$ & $234,17 \pm 11$ & $208,35 \pm 131,3$ & $350,15 \pm 17$ \\
\hline & & & 우/4 & 0,7 & 22 &, 70 & 4,36 & 5 & 6,99 \\
\hline
\end{tabular}




\begin{tabular}{|c|c|c|c|c|c|c|c|c|c|}
\hline & 3 & 11 & $0^{\pi} / 5$ & $\begin{array}{c}73,30 \pm 1 \\
5,5 \\
52,32 \pm 1 \\
2,1 \\
\end{array}$ & $\begin{array}{c}114,02 \pm 12 \\
, 4 \\
101,23 \pm 7 \\
53\end{array}$ & $\begin{array}{c}161,04 \pm 22 \\
, 64 \\
151,90 \pm 21 \\
, 89\end{array}$ & $\begin{array}{c}211,62 \pm 18 \\
13 \\
212,80 \pm 32 \\
70\end{array}$ & $\begin{array}{l}252,32 \pm 24,65 \\
280,73 \pm 55,50\end{array}$ & $\begin{array}{c}289,30 \pm 27 \\
69 \\
340,18 \pm 74 \\
29\end{array}$ \\
\hline 5 & 1 & 10 & $\begin{array}{l}0 / 7 \\
+/ 3\end{array}$ & $\begin{array}{c}60,64 \pm 1 \\
7,5 \\
48,43 \pm 1 \\
4,2 \\
\end{array}$ & $\begin{array}{c}104,13 \pm 12 \\
, 2 \\
89,17 \pm 28 \\
60\end{array}$ & $\begin{array}{c}158,84 \pm 33 \\
, 38 \\
145,53 \pm 43 \\
, 72\end{array}$ & $\begin{array}{c}206,30 \pm 35 \\
64 \\
232,40 \pm 84 \\
00\end{array}$ & $\begin{array}{c}266,76 \pm 39,36 \\
315,33 \pm 110,0 \\
4\end{array}$ & $\begin{array}{c}323,74 \pm 54 \\
87 \\
415,60 \pm 15 \\
9,75\end{array}$ \\
\hline & 2 & 10 & $\begin{array}{l}0 / 6 \\
+/ 4\end{array}$ & $\begin{array}{c}71,55 \pm 1 \\
1,2 \\
61,95 \pm 1 \\
6,7\end{array}$ & $\begin{array}{c}116,55 \pm 20 \\
, 1 \\
100,18 \pm 11 \\
, 7\end{array}$ & $\begin{array}{c}171,35 \pm 30 \\
, 55 \\
142,20 \pm 30 \\
, 70\end{array}$ & $\begin{array}{c}232,27 \pm 37 \\
04 \\
187,90 \pm 22 \\
98\end{array}$ & $\begin{array}{l}292,73 \pm 80,60 \\
240,98 \pm 19,61\end{array}$ & $\begin{array}{c}343,82 \pm 96 \\
28 \\
292,10 \pm 29 \\
04\end{array}$ \\
\hline & 3 & 9 & $\begin{array}{l}0 / 5 \\
\$ / 4\end{array}$ & $\begin{array}{c}70,32 \pm 1 \\
0,5 \\
49,70 \pm 1 \\
0,3\end{array}$ & $\begin{array}{c}112,22 \pm 24 \\
, 5 \\
76,90 \pm 9,7 \\
4\end{array}$ & $\begin{array}{c}173,66 \pm 49 \\
, 08 \\
142,08 \pm 45 \\
, 48\end{array}$ & $\begin{array}{c}213,16 \pm 40 \\
02 \\
198,38 \pm 44 \\
29\end{array}$ & $\begin{array}{l}250,98 \pm 47,46 \\
287,35 \pm 53,22\end{array}$ & $\begin{array}{c}290,12 \pm 52 \\
53 \\
375,65 \pm 86 \\
69\end{array}$ \\
\hline & $\mathrm{X}$ & $\begin{array}{c}14 \\
4\end{array}$ & $\begin{array}{c}0 / 7 \\
8\end{array}$ & $\begin{array}{c}69,31 \pm 4, \\
24\end{array}$ & $\begin{array}{c}117,10 \pm 7 \\
70\end{array}$ & $\begin{array}{c}169,50 \pm 14 \\
, 91\end{array}$ & $\begin{array}{c}228,74 \pm 17 \\
71\end{array}$ & $284,19 \pm 24,13$ & $\begin{array}{c}342,59 \pm 28 \\
31\end{array}$ \\
\hline & & & $\begin{array}{c}+9 / 6 \\
6\end{array}$ & $\begin{array}{c}58,32 \pm 4 \\
73\end{array}$ & $\begin{array}{c}99,75 \pm 9,2 \\
6\end{array}$ & $\begin{array}{c}155,75 \pm 18 \\
, 51\end{array}$ & $\begin{array}{c}210,85 \pm 28 \\
24\end{array}$ & $\begin{array}{c}273,10 \pm \\
33,8\end{array}$ & $\begin{array}{c}336,23 \pm 46 \\
71\end{array}$ \\
\hline
\end{tabular}

\section{Analisis Genetik Keturunan Ayam Tolaki}

\section{Komponen Variansi Berat Badan}

Keragaman genetik berat badan keturunan ayam Tolaki berdasarkan kelompok umur disajikan pada Tabel 5

Tabel 5. Komponen Variansi Genetik Berat Badan Berdasarkan Umur 0 - 12 Minggu.

\begin{tabular}{|c|c|c|c|c|}
\hline \multirow{2}{*}{$\underset{\text { (minggu) }}{\text { Umur }}$} & \multicolumn{4}{|c|}{ Komponen variansi genetik } \\
\hline & $\bar{\sigma}_{\mathrm{s}}^{2}$ & $\sigma_{d}^{2}$ & $\sigma_{\epsilon}^{2}$ & $\sigma^{2}{ }_{\text {total }}$ \\
\hline 0 & 0,52 & $-0,09$ & 6,96 & 7,39 \\
\hline 1 & 4,9 & 0,15 & 45,91 & 50,97 \\
\hline 2 & 27,63 & 0,95 & 241,34 & 269,91 \\
\hline 3 & 56,68 & 16,35 & 361,09 & 434,12 \\
\hline 4 & 104,35 & 28,03 & 462,99 & 595,38 \\
\hline 5 & 136,76 & 18,93 & 846,14 & 1001,82 \\
\hline 6 & 214,62 & $-36,89$ & 1389.58 & 1572,79 \\
\hline 7 & 235,15 & 24,590 & 1679,39 & 1939,14 \\
\hline 8 & 303,84 & $-154,74$ & 2350.37 & 2499,46 \\
\hline 9 & 337,57 & $-205,34$ & 3442,73 & 3425,34 \\
\hline 10 & 322,42 & $-194,11$ & 4216,37 & 4344,68 \\
\hline 11 & 559,06 & $-281,18$ & 5392,57 & 5604,68 \\
\hline 12 & 491,23 & $-415,68$ & 7299,77 & 7375,32 \\
\hline $\begin{array}{l}\text { Kol } \\
\text { (ind }\end{array}$ & $\begin{array}{l}\text { variansi jantan } \\
\text { rror) }\end{array}$ & $\sigma_{\epsilon}^{2}$ & Komponen & keturunan \\
\hline$\sigma^{2}$ total & variansi total & $\sigma_{d}^{2}$ & Kompone & i betina \\
\hline
\end{tabular}


Efek jenis kelamin. Pengamatan selama 12 minggu penelitian menunjukan pertumbuhan ayam jantan lebih cepat dibandingkan pertumbuhan ayam betina. Berat badan ayam jantan dan betina pada umur 12 minggu masing-masing 342,59 gram dan 336,2 gram. (lihat Tabel 4). Hal ini sesuai dengan ayam kampung pada umumnya yang sudah menunjukan kecendrungan munculnya sex-dimorphism pada awal pertumbuhan dimana jantan lebih berat dari betina. . Astuti et al (1978), menyatakan bahwa sejak menetas sampai umur 2 minggu pertumbuhan ayam kampung jantan dan betina tidak berbeda nyata, tetapi setelah umur 2 minggu secara nyata ayam jantan tumbuh lebih cepat dibandingkan dengan ayam betina karena pengaruh sex-demorphism aksi biologis dari hormon kelamin.

\section{Pendugaan Nilai Heritabilitas Berat Badan}

Pendugaan nilai heretabilitas berat badan keturunan Ayam Tolaki berdasarkan umur disajikan pada Tabel 6 .

Tabel 6. Pendugaan Nilai Heritabilitas Berat Badan Umur 0 sampai 12 Minggu

\begin{tabular}{cccc}
\hline Umur (Minggu) & \multicolumn{3}{c}{ Heritabilitas } \\
\hline & $\hat{\mathbf{h}}_{\mathbf{s}}{ }_{\mathbf{s}}$ & $\hat{\mathbf{h}}_{\mathbf{d}}{ }_{\mathbf{d}}$ & $\hat{\mathbf{h}}_{(\mathbf{s}+\mathbf{d})}$ \\
\hline 0 & $0,28 \pm 0,29$ & $-0,05 \pm 0,11$ & $0,12 \pm 0,13$ \\
1 & $0,39 \pm 0,33$ & $0,01 \pm 0,08$ & $0,20 \pm 0,23$ \\
2 & $0,41 \pm 0,35$ & $0,01 \pm 0,13$ & $0,21 \pm 0,24$ \\
3 & $0,52 \pm 0,38$ & $0,15 \pm 0,21$ & $0,34 \pm 0,31$ \\
4 & $0,70 \pm 0,45$ & $0,19 \pm 0,13$ & $0,44 \pm 0,25$ \\
5 & $0,55 \pm 0,42$ & $0,08 \pm 0,13$ & $0,31 \pm 0,29$ \\
6 & $0,54 \pm 0,41$ & $-0,08 \pm 0,26$ & $0,23 \pm 0,26$ \\
7 & $0,49 \pm 0,38$ & $0,05 \pm 0,15$ & $0,27 \pm 0,27$ \\
8 & $0,49 \pm 0,38$ & $-0,25 \pm 0,27$ & $0,12 \pm 0,13$ \\
9 & $0,39 \pm 0,33$ & $-0,24 \pm 0,26$ & $0,08 \pm 0,14$ \\
10 & $0,30 \pm 0,28$ & $-0,18 \pm 0,19$ & $0,06 \pm 0,12$ \\
11 & $0,39 \pm 0,33$ & $-0,20 \pm 0,21$ & $0,09 \pm 0,16$ \\
12 & $0,27 \pm 0,26$ & $-0,23 \pm 0,23$ & $0,02 \pm 0,07$ \\
\hline
\end{tabular}

$\overline{\mathrm{h}}_{\mathrm{s}}^{2}$ : komponen pejantan $\quad \hat{\mathrm{h}}_{(\mathrm{s}+\mathrm{d})}^{2}$ : gabungan komponen jantan dan induk

$\hat{\mathrm{h}}_{\mathrm{d}}^{2}$ : komponen betina 
Pendugaan nilai heritabilitas berdasarkan komponen pejantan $\left(\hat{\mathrm{h}}_{\mathrm{s}}^{2}\right)$ terendah pada umur 12 minggu yakni 0,27 dan tertinggi pada umur 4 minggu yakni 0,70 . Pendugaan nilai heritabilitas berdasarkan komponen induk $\left(\hat{\mathrm{h}}_{\mathrm{d}}^{2}\right)$ bernilai positif pada umur 1 sampai 5 minggu dan kemudian kembali bernilai positif pada umur 7 minggu. Sedangkan pada umur 0, 6 minggu bernilai negatif kemudian pada umur 8 sampai 12 minggu kembali bernilai negatif yang berarti penampilan genetik yang bersifat gen aditif tidak tampak. Pendugaan nilai heritabilitas berdasarkan gabungan komponen variansi pejantan dan induk yang merupakan pendugaan nilai heritabilitas individu bernilai positif pada setiap umur dari 0 sampai 12 minggu,

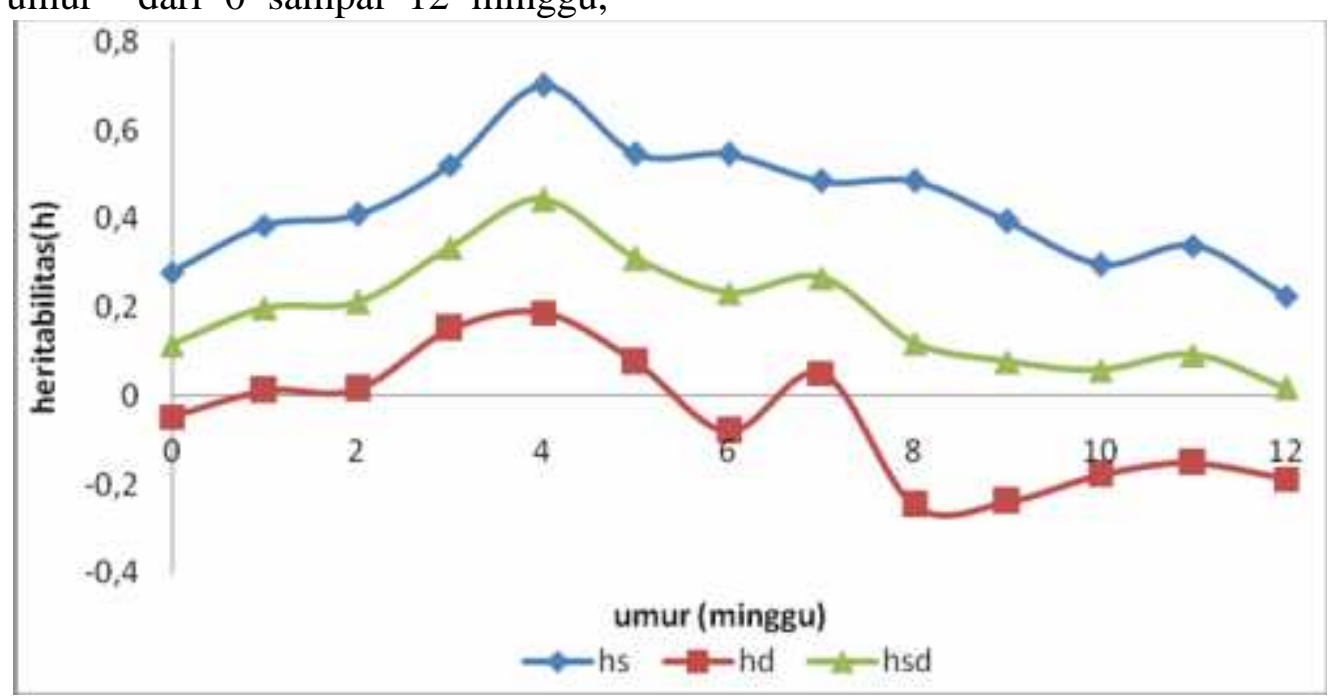

Gambar 1. Pendugaan nilai heritabilitas berat badan umur 0 sampai 12 minggu

Nilai heritabilitas berdasarkan komponen pejantan $\left(\hat{\mathrm{h}}_{\mathrm{s}}^{2}\right)$, menunjukan kemampuan yang lebih tinggi bila dibandingkan dari komponen variansi induk $\left(\hat{\mathrm{h}}_{\mathrm{d}}^{2}\right)$, dan komponen variansi gabungan pejantan dan induk $\left(\hat{\mathrm{h}}_{\mathrm{s}+\mathrm{d}}^{2}\right)$ dari umur 0 sampai 12 minggu, hal ini disebabkan karena dengan meningkatnya umur kemampuan beradaptasi dengan dimana nilai heritabilitas yang ditampilkan menunjukan nilai heritabilitas yang sudah didefinisikan berada diantara 0 sampai 1 . Pirchner disitasi Kismiati (1997), komponen variansi pejantan dan induk merupakan pengaruh genetik yang merupakan gabungan pejantan dan induk secara bersama-sama (gen aditif, dominan dan epistasi).

Perkembangan nilai heritabilitas komponen berat badan berdasarkan komponen variansi pejantan, induk dan gabungan pejantan dan induk dapat dilihat pada Gambar 1. 


\section{Pertambahan Berat Badan}

Komponen variansi pertambahan berat badan pada umur 0-1 sampai 11-12 minggu. Disajikan pada Pada Tabel 7.

Tabel 7. Komponen Variansi Genetik Pertambahan Berat Badan Berdasarkan Umur 0-1 sampai 11-12 Minggu

\begin{tabular}{ccccc}
\hline & \multicolumn{4}{c}{ Komponen Variansi Genetik } \\
\cline { 2 - 5 } Umur (minggu) & $\mathbf{\sigma}_{\mathbf{s}}{ }^{2}$ & $\mathbf{\sigma}_{\mathbf{d}}{ }^{2}$ & $\boldsymbol{\sigma}_{\mathbf{e}}{ }^{2}$ & $\boldsymbol{\sigma}^{2}$ total \\
\hline $0-1$ & 2,47 & $-0,02$ & 29,53 & 31,98 \\
$1-2$ & 10,48 & $-1,32$ & 105,59 & 114,74 \\
$2-3$ & 7,57 & 0,37 & 77,595 & 85,538 \\
$3-4$ & 8,14 & 0,19 & 115,53 & 123,86 \\
$4-5$ & 9,67 & $-8,11$ & 206,38 & 207,93 \\
$5-6$ & 13,36 & $-9,49$ & 281,23 & 285,10 \\
$6-7$ & 16,28 & 9.91 & 416,99 & 443,16 \\
$7-8$ & 4,42 & $-11,29$ & 221,26 & 214,38 \\
$8-9$ & 9,29 & $-23,00$ & 437,44 & 423,72 \\
$9-10$ & 7,29 & 4,55 & 282,87 & 294,705 \\
$10-11$ & 55,06 & $-25,86$ & 396,61 & 425,82 \\
$11-12$ & 15,60 & $-13,53$ & 372,99 & 375,16 \\
\hline s $^{2}:$ Komponenvariansi jantan & $\sigma^{2}:$ Komponen variansi keturunan (individual error) \\
$\sigma^{2}$ total : Komponen variansi total & $\sigma^{2}{ }^{2}$ Komponen variansi betina &
\end{tabular}

Penyebaran komponen variansi pertambahan berat badan, terlihat bahwa komponen variansi pejantan $\left(\sigma_{\mathrm{s}}^{2}\right)$ yang merupakan kemampuan pejantan dalam pendugaan gen aditif dari umur 0 sampai dengan 12 minggu bernilai positif. Penyebaran komponen variansi betina $\left(\sigma_{d}^{2}\right)$ yang merupakan genetik dari gen aditif juga oleh gen non- aditif (dominan, epistasi dan interaksi) bernilai negatif pada umur $0-1 ; 1-2 ; 4-5 ; 5-6 ; 7-8 ; 8-9 ; 10-11$ dan 11-12 minggu sedang pada umur 2-3,; 3-4; 6-7 dan 9-10 minggu komponen variansi betina bernilai positif

Munculnya komponen variansi induk $\left(\sigma_{d}^{2}\right)$ yang negatif pada beberapa periode umur diduga karena faktor lingkungan yang cukup besar variasi yang sulit dideteksi mengakibatkan beragamnya sifat pertumbuhan diantara umur pada keturunan ayam Tolaki (Laviere. J M at al., 2009).

Penyebaran komponen variansi keturunan/individual eror $\left(\sigma^{2} \epsilon\right)$ lebih besar dibandingkan komponen variansi pejantan $\left(\sigma_{s}^{2}\right)$ maupun komponen variansi induk $\left(\sigma_{d}^{2}\right)$. Besarnya komponen variansi keturunan $\left(\sigma^{2} \epsilon\right)$ yang merupakan komponen variansi lingkungan merupakan indikasi besarnya pengaruh lingkungan terhadap pertambahan berat badan (Sidadolog, 1998)

\section{Pendugaan Nilai Heritabilitas PBB}

Pada Tabel 8 disajikan nilai heritabilitas pertambahan berat badan umur 0-1 sampai 11-12 minggu.

Penyebaran komponen variansi pertambahan berat badan, terlihat bahwa komponen variansi pejantan $\left(\sigma_{\mathrm{s}}^{2}\right)$ yang merupakan kemampuan pejantan dalam pendugaan gen aditif dari umur 0 sampai dengan 12 minggu bernilai positif. Penyebaran komponen variansi betina $\left(\sigma_{d}^{2}\right)$ yang merupakan genetik dari gen aditif juga oleh gen non- aditif (dominan, epistasi dan interaksi) bernilai negatif pada umur $0-1 ; 1-2 ; 4-5 ; 5-6 ; 7-8 ; 8-9 ; 10-11$ dan 11-12 minggu sedang pada umur 2-3; 3-4; 6-7; dan 9-10 minggu komponen variansi betina bernilai positif. 
Tabel 8. Pendugaan Nilai Heritabilitas PBB Berdasarkan Umur 0-12 Minggu

\begin{tabular}{cccc}
\hline & \multicolumn{3}{c}{ Heritabilitas } \\
\cline { 2 - 4 } Umur (Minggu) & $\hat{\mathbf{h}}_{\mathbf{s}}^{\mathbf{2}}$ & $\hat{\mathbf{h}}_{\mathbf{d}}^{\mathbf{2}}$ & $\hat{\mathbf{h}}_{(\mathbf{s}+\mathbf{d})}$ \\
\hline $0-1$ & $0,32 \pm 0,23$ & $-0,03 \pm 0,02$ & $0,16 \pm 0,22$ \\
$1-2$ & $0,37 \pm 0,32$ & $-0,05 \pm 0,11$ & $0,15 \pm 0,22$ \\
$2-3$ & $0,35 \pm 0,31$ & $0,01 \pm 0,21$ & $0,19 \pm 0,23$ \\
$3-4$ & $0,26 \pm 0,27$ & $0,06 \pm 0,09$ & $0,13 \pm 0,27$ \\
$4-5$ & $0,19 \pm 0,22$ & $-0,16 \pm 0,09$ & $0,01 \pm 0,21$ \\
$5-6$ & $0,19 \pm 0,27$ & $-0,13 \pm 0,18$ & $0,03 \pm 0,11$ \\
$6-7$ & $0,15 \pm 0,20$ & $0,09 \pm 0,15$ & $0,12 \pm 0,26$ \\
$7-8$ & $0,08 \pm 0,15$ & $-0,21 \pm 0,24$ & $-0,06 \pm 0,18$ \\
$8-9$ & $0,09 \pm 0,15$ & $-0,21 \pm 0,24$ & $-0,06 \pm 0,18$ \\
$9-10$ & $0,10 \pm 0,16$ & $0,06 \pm 0,13$ & $0,08 \pm 0,07$ \\
$10-11$ & $0,52 \pm 0,29$ & $-0,24 \pm 0,18$ & $0,14 \pm 0,16$ \\
$11-12$ & $0,17 \pm 0,19$ & $-0,14 \pm 0,20$ & $0,01 \pm 0,08$ \\
\hline
\end{tabular}

$\widehat{\mathrm{h}}_{\mathrm{s}}^{2}$ : komponen pejantan $\quad \hat{\mathrm{h}}_{\mathrm{s}+\mathrm{d} \text { : }}^{2}$ komponen gabungan pejantan dan betina

$\hat{\mathrm{h}}_{\mathrm{d}}^{2}$ : komponen betina

Hasil penelitian keturunan ayam Tolaki menunjukkan besarnya pewarisan sifat genetik pertambahan berat badan menunjukkan nilai heritabilitas tinggi berdasarkan gen aditif umur $0-3$ minggu dan pada umur 10 - 11 minggu, nilai sedang pada umur 3 - 7 minggu, 9 - 10 dan umur 11 -12 minggu, nilai rendah pada umur $7-9$ minggu. Pendugaan heritabilitas berdasarkan komponen pejantan (saudara tiri sebapak) paling banyak digunakan dan paling murni untuk ragam genetik aditif diantara metode yang ada, apabila dikerjakan dengan tepat (Adeyinka I.A. et al., 2006).

\section{KESIMPULAN}

Berdasarkan hasil penelitian yang dilaksanakan terhadap Analisis Genetik Ayam Tolaki pada Masa Pertumbuhan dapat disimpulkan sebagai berikut:

1. Pewarisan sifat pertumbuhan berdasarkan komponen variansi pejantan $\left(\hat{\mathrm{h}}_{\mathrm{s}}^{2}\right)$, berdasarkan induk $\left(\hat{\mathrm{h}}_{\mathrm{d}}^{2}\right)$ serta pejantan dan induk $\left(\hat{\mathrm{h}}^{2}{ }_{\mathrm{s}+\mathrm{d}}\right)$ cukup berfluktuasi yang menggambarkan masih luasnya variansi sifat pertumbuhan ayam Tolaki

2. Kemampuan pewarisan sifat pertumbuhan berdasarkan komponen variansi pejantan $\left(\hat{\mathrm{h}}_{\mathrm{s}}^{2}\right)$ umur 0 sampai 12 minggu dengan nilai heritabilitas tinggi dan bernilai positif.

\section{DAFTAR PUSTAKA}

Anonimous, 2008.Ayam Lokal Indonesia. $w w w$. Sentral ternak.Com $(O n: 19$ Juli 2009)

Astuti, M., H. Mulyadi dan J.H.P Sidadolog. 1979. Pengukuran Parameter Ayam Kampung I Bobot Badan dari Tetua, Korelasi anatara Bobot Badan pada Umur 1 Hari, 4,8,12 dan 22 Minggu. Laporan Penelitian. No.298/PIT/DPPM,1978. Fakultas Peternakan. UGM, Yogyakarta.

Becker, A. W. 1992. Manual of Quantitative Genetics. Washington State University, Washington USA. 
Iswanto, 2005. Ayam Kampung Pedaging. PT Agromedia Pustaka. Jakarta.

J.M.Lariviere,c. Michaux, V. Verleyen and P. Leroy. 2009. Poultry science 8(10) : 952-956. Interstate Publishers Inc.

IA. Adeyinka, O.O. Oni, B.I Nwagu and F.D. Adeyinka. 2006. Poultry science 5(6) : 589-592. Interstate Publishers Inc.

Kismiati, 1997. Pengaruh Interval Inseminasi terhadap Performan Reproduksi dan Heritabilitas Pertumbuhan Ayam Kedu Hitam. Tesis-S2. Program Pasca Sarjana Fakultas Peternakan UGM Yogyakarta.

Nafiu, L.D., dan M. Rusdin. 2007. Studi Potensi dan Keragaman Ayam Lokal di Sulawesi Tenggara. Laporan Penelitian. Lembaga Penelitian Unhalu. Unpublished. Kendari

Nataamijaya, A.G., dan Dwiyanto 1994. Konservasi Ayam Buras (Pelung, Nunukan, Gaok, Kedu Putih Sentul dan Jenis Ayam Kampung Lainnya). Laporan Hasil Penelitian Balai Penelitian Ternak bekerja sama dengan Proyek Pembangunan Penelitian Pertanian Nasional. Badan Penelitian dan Pengembangan Pertanian. Bogor.

O.O. Oni, B.Y. Abubakar, N.I. Dim. O.E. Asiribo and I.A. Adeyinka. 2007. Poultry science 6(1) : 8-1-2007. Interstate Publishers Inc.

Sarwono, B., 2007. Beternak Ayam Buras. Penebar Swadaya. Jakarta.

Sidadolog, J.H.P., 1998. Perbaikan Produksi Ayam di Daerah Tropis Melalui Manipulasi Genetikdan Pakan. Pidato Pengukuhan jabatan
Lektor Kepala. Fakultas Peternakan Universitas Gadjah Mada. Yogyakarta. 